\title{
Rörelser i tiden. \\ Professionalisering och \\ privatisering i socialt arbete
}

PETER DELLGRAN \& STAFFAN HÖJER

\begin{abstract}
Vidareutbildningar, handledning och ackumulerade yrkeserfarenheter kan alla ses som inslag $i$ socionomers individuella professionalisering. I denna artikel visas hur socionomernas karriärvägar kännetecknas av förflyttningar frän områden med lägre status och autonomi till områden med högre sådan. Även privatisering kan utifrån ett individuellt perspektiv tolkas som en professionaliseringsstrategi.
\end{abstract}

\section{Inledning}

Omvandlingen av den svenska välfärdsstaten och dess uppgifter inom vård, skola och omsorg är trots de senaste decenniernas dramatik också en fråga om kontinuerlig förändring. Organiseringen av den offentliga tiänsteproduktionen är betingad av ett komplicerat och fortlöpande samspel mellan yttre och inre faktorer, mellan kortsiktiga och mer långsiktiga skeenden, men också mellan olika aktörers intressen, överväganden och strategier för att bemäs-

Peter Dellgran och Staffan Höjer är båda docenter i socialt arbete vid Göteborgs universitet. tra strukturella och resursmässiga villkor. I centrum av dessa processer återfinns samspelet mellan politisk styrning och förvaltning av verksamhetsdomäner å ena sidan och professionalisering av yrkesområden å den andra.

Mot bakgrund av en mångårig strävan mot professionalisering av det sociala arbetet, och de senaste årens strukturella förändringar av de offentliga välfärdstjänsterna, har denna artikel två nära relaterade huvudsyften. För det första är avsikten att på ett sammanhållet vis beskriva och diskutera professionaliseringsmässiga skillnader mellan den mångfald av olika arbetsområden som sammantaget utgör socionomer- 
nas yrkesfält. Därigenom kommer vi att behandla flera frågeställningar; (1) Hur har professionaliseringen av det sociala arbetet i Sverige gestaltat sig vad gäller t.ex. vidareutbildning, handledning och auktorisation?; (2) I vilken utsträckning har dessa ansträngningar resulterat i en obalanserad utveckling mellan olika områden vad gäller t.ex. arbetsvillkor, formell kompetens, status eller lönenivåer? Är vissa arbetsfält mer professionaliserade i dessa meningar än andra, och i så fall, varför och med vilka konsekvenser? Sådana skillnader talas det påfallande ofta om i termer av stratifiering och hierarkiska statusordningar, men är mycket sällan föremål för empiriska undersökningar (Nygren 2000, Dellgran \& Höjer 1999); (3) Hur utfaller en motsvarande jämförelse av professionalisering mellan socionomer som är offentligt anställda och de som bedriver socialt arbete i egen, privat regi? Vårt intresse för det sistnämnda har sitt ursprung i två aktuella forskningsprojekt om privatisering, socialt arbete i privata former och professionsrelaterade motiv till sådant. ${ }^{1}$ I denna artikel kommer vi också att beröra dessa motiv och vilken typ av tjänster och arbetsområden som präglar de privata socionomernas verksamhet.

Vårt andra huvudsyfte är att belysa flyttningsmönster och karriärvägar inom socionomkollektivet, framför allt med avseende på rörelserna mellan olika arbetsområden och mellan offentligt och privat utfört soci-

1 Det handlar dels om ett tidigare projekt finansierat av CEFOS (Centrum för forskning om offentlig sektor) vid Göteborgs universitet, dels ett pågående projekt finansierat av FAS (Forskningsrådet för arbetsliv och socialvetenskap). alt arbete. Hur vanligt är det t.ex. med byte från traditionellt socialbyråarbete till andra områden och arbetsuppgifter, och i vilken mån kan sådana rörelser kopplas till professionalisering och strävan efter ökat professionellt inflytande, bättre betalda arbeten eller ökad status? ${ }^{2}$ Dessutom kommer vi att granska i vilken utsträckning det går att skönja tendenser till ökning av det som vi här har benämnt som en professionsdriven privatisering.

För båda våra ändamål utgår vi från en omfattande enkät med exakt 1000 svarande yrkesverksamma socionomer. Komparationerna mellan olika arbetsområden respektive offentligt och privat verksamma bygger på ett antal professionaliseringsindikatorer som bland annat inbegriper vidareutbildning, yrkeserfarenheter, förekomsten av handledning, auktorisation, arbetsvillkor, orientering mot forskning och vetenskaplig kunskap men även lönenivåer och statusbedömningar. När det gäller frågan om rörligheten på arbetsmarknaden utgår vi från en jämförelse av hur tre olika utbildningsgenerationer fördelar sig på olika arbetsområden respektive offentlig kontra privat anställning. Innan det empiriska materialet och de analytiska ansatserna beskrivs närmare ska vi presentera några teoretiska utgångspunkter. I detta ingår att diskutera på vilka sätt privatiseringsfenomenet kan förstås i termer av professionalisering, något som gjorts i ganska liten utsträckning i Sverige men likväl förekommit från såväl politiskt som professionellt håll. I klart större

2 Däremot kommer vi inte att beröra administrativa och arbetsledningsmässiga karriärmönster.

Peter Dellgran \& Staffan Höjer: Rörelser i tiden. Professionalisering och... 
utsträckning har privatisering lanserats och diskuterats som en professionaliseringsstrategi i t.ex. USA (dock inte helt okontroversiellt, se t.ex. Specht \& Courtney 1994, Lowe \& Reid 1999).

\section{Professionalisering och det professionella projektet}

Professionalisering är ett mångfasetterat begrepp med olika innebörder beroende på vilket teoretiskt perspektiv man anlägger eller vilken nivå man betonar (Macdonald 1995, Freidson 1994, Burrage \& Torstendahl 1990). Ibland avses den allmänna samhällsprocess i vilken professionell expertis får ett växande inflytande över både politik och människors vardagsliv. Med en annan innebörd avses den socialisationsprocess inom vilken den enskilde via utbildning och tillägnandet av yrkesspecifik litteratur, språk och begrepp tar del av en viss professionell kultur och världsbild, och därigenom utvecklar en viss professionell identitet (som läkare, psykolog, förskolelärare, jurist, socionom etc.).

I en annan vanlig betydelse står professionalisering för de kollektiva strategier och medel som används för att organisera en enskild yrkesgrupps relationer, gränser och samspel med staten, andra professioner och allmänheten. Ofta utgår man från att detta är en process - $i$ huvudsak inducerad av yrkesgruppen själv och ofta benämnt som ett professionellt projekt - med målet att ernå anseende, legitimitet och ökad status. Ytterst handlar det om autonomi och kontroll över den egna utbildningens och yrkesutövningens innehåll och villkor.
Från ett Weberianskt perspektiv ser t.ex. Freidson (1994) och Larson (1977) professionen som en social grupp som skapar sig själv och utvecklar strategier för att bevara och förbättra den egna gruppens ställning. I enlighet med detta brukar välfärdsprofessionerna beskrivas som högutbildade grupper som i kraft av vetenskapligt baserad auktoritet och expertstatus har varit lyckosamma i att göra anspråk på och monopolisera vissa specifika yrkesområden. Antingen karakteriseras de, enligt en anglosaxisk idealtypisk professionsmodell i likhet med andra professionella grupper, som fria, konkurrerande entreprenörer på en marknad, eller som anställda experter inom den privata, offentliga eller tredje sektorn enligt en mer europeisk professionsmodell.

Det professionella projektet handlar således om att få samhällets sanktion och mandat att ensamt få utföra vissa typer av samhällsuppgifter (eller så kallad jurisdiktion). I fallet socionomer kan man peka ut en lång rad professionsstärkande aktiviteter som utgör delar av just socionomernas professionella projekt (Dellgran \& Höjer 2003a, Wingfors 2004); etableringen av begreppet socialt arbete vid förra sekelskiftet, socionomutbildningen, etableringen av examensbeteckningen socionom, kampen för professionell handledning (och sedermera handledarutbildningen), bildandet av intresseorganisationer och fackföreningar, utveckling av specifika teoribildningar, etablering av etiska regler, magisterutbildning och auktorisationssystem samt ansträngningarna att förvetenskapliga det praktiska arbetet genom sjösättningen av det akademiska ämnet och institutionaliseringen av 
forskningen. ${ }^{3}$ I vart och ett av dessa finns det gott om exempel på anspråk och gränsarbete (eller "boundary work", se Gieryn 1990, antingen för att stänga ute vissa grupper och verksamheter men också för att inkludera och inlemma nya områden). Både kunskapsområdet och yrkespraktiken har fortfarande en del öppna och oklara gränsytor till vissa andra professionella områden, vilket betyder att det finns en lång rad "boundary objects", dvs. aktiviteter och arbetsuppgifter som man konkurrerar med andra om. Familjeterapin är ett sådant exempel (Rigné 2002). Den här sidan av professionaliseringen kommer vi dock inte att beröra i denna artikel.

Till nyssnämnda lista kan också läggas nya fenomen som satsningen på särskilda FoU-enheter och kraven på en så kallad evidensbaserad praktik, eller nygamla tillskott på agendan om det sociala arbetets uppgifter som t.ex. "internationellt socialt arbete" och "anti-oppressive social work». ${ }^{4}$ Huruvida dessa exempel kan ses som professio-

3 Professionsteoretiskt kan man associera till den så kallade aspirantmodellen (McDonald 2003). Modellen bygger dock på en kritiserad, schematisk föreställning om "riktiga» professioner och "semiprofessioner" och att alla yrkesgrupper följer en idealtypisk utvecklingslinje. Varje professionellt projekt måste dock kontextualiseras och granskas empiriskt då enskilda yrkesgrupper kan ha en långt brokigare historia i sitt specifika gräns- och relationsarbete.

4 McDonald (2003) hävdar att en generell inriktning gentemot evidensbaserad praktik inte är något nytt utan att liknande formuleringar har följt professionen ända sedan Mary Richmond 1917 skrev Social Diagnosis, se också Kirk \& Reid (2002). nella strategier är naturligtvis en empirisk fråga, men de pekar på två mycket viktiga aspekter i all professionalisering. För det första att intresset för professionalisering av ett visst välfärdsområde eller yrkesgrupp kan drivas av vissa enskilda inomprofessionella grupperingar, och för det andra inte bara behöver komma från de yrkesverksamma själva. ${ }^{5}$ De två förstnämnda exemplen - FoU-enheterna och satsningen på ett kunskapsbaserat socialt arbete - är ju båda i mångt och mycket statligt och kommunalt pådrivna fenomen. På motsvarande sätt genomförs på kommunalt plan en lång rad åtgärder i syfte att professionalisera sina anställda genom kompetensstärkande insatser som t.ex. fortbildning.

Professionalisering är därmed också en fråga om implementering i samspel mellan de professionella och staten, kommunerna och andra arbetsgivare men också mellan kollektiva och individuella nivåer. Med individuell professionalisering avses en utveckling av speciella förmågor och kompetenser hos enskilda yrkesutövare, t.ex. via ackumulerade yrkeserfarenheter, specialisering, handledning eller vidareutbildning (Svensson 1998). Även den individuella professionaliseringen kan inkludera ett visst mått av gräns- och relationsarbete - för att vidga eller upprätthålla en uppgiftsdomän, inflytande, handlingsfrihet, status eller legiti-

5 Ett bra exempel på detta är äldreomsorgen, där man i den Nationella handlingsplanen pekar på att personalrekryteringsproblemet har att göra med bristande professionalisering av berörda yrkesgrupper. Detta anförs också som ett viktigt argument för det statliga stödet till etablering av regionala FoU-enheter på äldreområdet.

Peter Dellgran \& Staffan Höjer: Rörelser i tiden. Professionalisering och... 
mitet på den egna arbetsplatsen. Särskilt vanligt torde detta vara för socionomer som arbetar i organisationer där andra professionella grupper dominerar (som inom t.ex. skolan eller sjukvården). Individuell professionalisering kan ske såväl inom befintliga tjänster och arbetsuppgifter som i form av det som vi i den här artikeln kommer att fästa särskild vikt vid, nämligen byte av arbetsuppgifter och verksamhetsfält.

En ytterligare aspekt av professionalisering tar fasta på att alla professioner och professionella i princip bara kan uppnå relativ autonomi gentemot t.ex. staten och sina arbetsgivare. Beroendet av stat och politik innebär att det inte är givet att de omständigheter och villkor under vilka man opererar består. Alla yrkesområden är kontinuerligt utsatta för olika typer av förändringar som utmanar den kunskapsdomän som man i varierande grad har lyckats göra till sin egen; nya kunskaper och tekniker, framväxten av specialiseringar och nya yrkesgrupper, informationsteknologins utveckling, ny lagstiftning, förändrade ekonomiska villkor, nya organisationsformer, en tilltagande internationalisering, nya kvalitetskrav och sociala behov osv. Varje profession måste alltså utveckla sin förmåga att hantera förändringar som hotar att försvaga dess kompetens och de risker för förändrade villkor för professionell utveckling som detta medför (Becher 1999). Några exempel på svensk forskning som berör sådana frågor är Bloms (1998) studie av konsekvenserna av marknadsorientering och Svenssons (1998) studie av effekterna av decentralisering av den kommunala organisationen. I stort har vi dock en relativt begränsad kunskap om hur förändringarna inom den offentliga sektorn under de senaste decennierna har påverkat socionomernas arbetssituation och villkor för professionell utveckling.

\section{Privatisering som professionalisering?}

Frågan är då om också privatisering kan sägas vara en individuell professionaliseringsstrategi eller tänkbar komponent i ett professionellt projekt. Framför allt i den allmänna socialpolitiska debatten, men också i forskningen, har privatiseringar vanligtvis betraktats som en del i ett politiskt, mer eller mindre, planerat projekt (som tillsammans med marknadsorientering och decentralisering utgör den strömning som i internationell litteratur hänförs till »New Public Management»). Av ekonomiska och/ eller ideologiska skäl har man i kommuner och landsting helt eller delvis avyttrat verksamhetsdelar och tjänster som man tidigare haft ett totalansvar för (dvs. såväl reglerat, finansierat som producerat), för att i stället köpa tjänster av andra utförare.

I forskningen kring privatiseringens orsaker och bakomliggande mekanismer görs ibland en åtskillnad mellan policydriven (dvs. genomförd på grundval av politiska beslut) respektive efterfrägedriven privatisering (genom att det offentliga inte uppfattas kunna eller vilja tillfredsställa ett visst servicebehov i offentliga former, se t.ex. Starr 1989). Samtidigt borde ökningen av offentligt finansierade tjänster utförda av privata aktörer innebära att vi kan tala om en spontan privatisering i betydelsen av att tidigare offentliganställda går över till den privata sektorn eller startar egen, 
privat verksamhet. Forskningsmässigt har man dock sällan fokuserat på utbudsfaktorer och om man kan identifiera ett inslag av professionsdriven privatisering. Med tanke på den centrala betydelse som välfärdsprofessionerna tidigare har tillskrivits för välfärdsstatens expansion, ter det sig idag lite märkligt att man har ägnat såpass lite uppmärksamhet åt frågan om hur dessa yrkesgrupper påverkas av välfärdsstatens omvandling under de senaste decennierna men också om de själva påverkar t.ex. privatiseringstendenserna.

Ur ett professionsteoretiskt perspektiv kan drivkrafterna bakom privatisering för det första ses som en individuell strategi för ökad handlingsfrihet, självständighet och kontroll över det egna arbetets organisering och innehåll. Det privata alternativet kan för den enskilde socionomen locka med högre status och inkomster, en högre grad av frihet och en ökad möjlighet att själv få bestämma över sitt arbete. Att gå över till privat verksamhet skulle för det andra kunna ses som en strategi för att hantera missnöje och/eller att hantera förändringar av olika slag. Privatisering kan med andra ord vara en reaktion på utvecklingstendenser inom kommunal byråkrati och förvaltning som gör att enskilda socionomer upplever försämrade arbetsvillkor. Irritation över nedskärningar, tilltagande ekonomisering (Pettersson 1994), konflikter med lokala politiker eller återkommande omorganisationer kan få till effekt att det stöter ut offentliganställda socionomer som ser sin professionella kompetensutövning och sina utvecklingsmöjligheter beskurna. Med tanke på diskussionen om svårigheterna att kombinera myndighetsutövning och kon- troll med stöd av olika slag till klienter kan också ett ökat inslag av kontroll på socialkontoren spä på incitamenten till att lämna den typen av arbete. Att starta eget kan alltså te sig som en strategi för att motverka riskerna för deprofessionalisering.

Diskussionen om professionaliseringen i socialt arbete har sedan länge varit omfattande men relativt få studier har granskat vad den faktiskt har inneburit för klienter, socialarbetare eller samhället i övrigt (Camilleri 1996, Payne 1996, Dellgran \& Höjer 2000). Detsamma kan sägas om privatisering och dess relation till professionalisering. Framför allt i USA, där inslaget av privat socialt arbete är avsevärt större och dessutom växande, finns en viss forskning kring sambandet (Alexander 1987, Peat \& Costley 2000, Kayser \& Rothstein 1997, Jayaratne et al. 1991, Chunget et al. 1995, Butler 1992, Strom 1994). Även i Storbritannien (Manthorpe \& Stanley 1997, Harris 2004), Australien (Munn \& Kennedy 1994, Martin 1992, Rosenman 1989) och Nya Zeeland (van Heugten \& Daniels 2001) har privatiseringsfrågan diskuterats i professionaliseringstermer. Men medan man i USA mer stöter på talet om privatisering som något som förstärker professionell autonomi och handlingsfrihet, är uppfattningen i Storbritannien ofta den omvända, nämligen att privatiseringen (som i det brittiska exemplet vanligtvis uppfattas som politiskt och uppifrån planerat) istället hotar socialarbetarnas professionella diskretion (för en översikt se Evans \& Harris 2004). Det står helt klart att vi inte haft samma utveckling och diskussion i Sverige. Att professionellt socialt arbete i huvudsak både bedrivs och bör regleras, utföras och finansieras av väl- 
färdsstaten är en långt vanligare uppfattning här än i t.ex. USA, såväl bland socionomer som allmänheten (se också Dellgran \& Höjer 2003a).

\section{Material och metoder - om professionaliserings- indikatorer och generationsjämförelser}

Vår ambition är således att dels granska professionaliseringsrelaterade skillnader mellan olika arbetsområden, dels belysa professionalisering i termer av yrkesmässiga karriärer uppåt (till områden med högre grad av status och autonomi) och utåt (från offentligt till privat socialt arbete). Det empiriska materialet är som nämndes insamlat inom ramen för en enkät som ingår i ett större forskningsprojekt som också inkluderar ett antal intervjuer med socionomer med privat verksamhet. ${ }^{6}$ Enkäten riktades till ett slumpvis urval på totalt 2000 medlemmar i Akademikerförbundet SSR. Med hänsyn taget till att SSR:s medlemmar också består av andra yrkesgrupper (som därför också ingick i vårt urval) motsvarar antalet svarande med socionomexamen en reell svarsfrekvens på 72 procent (se vidare Dellgran \& Höjer 2003b).

Akademikerförbundet SSR organiserar idag cirka 80 procent av Sveriges yrkes-

6 Vid insidan om den aktuella enkäten har också gjorts en enkät med 801 svarande socionomstudenter vid sju olika socionomutbildningar samt kvalitativa intervjuer med ett trettiotal socionomer som bedriver socialt arbete i egen privat regi. verksamma socionomer. Övriga är antingen medlemmar i SKTF eller i andra (alternativt inget) fackförbund. Då vi från intervjuerna vet att en del av de socionomer som har en egen firma väljer att gå ur SSR (eller SKTF) finns en viss risk för underskattning av den reella andelen socionomer med egen privat verksamhet. Vi har här inte heller någon möjlighet att beskriva professionaliseringen bland SKTF-anslutna socionomer.

Jämförelsen mellan olika arbetsområden utgår från respondenternas egna placeringar i ursprungligen 24 namngivna områden som i denna artikel har reducerats till tolv (se Tabell 1). Detta innebär att t.ex. social barnavård - det i särklass största området - innefattar arbete med barn, familjer och ungdomar på socialkontor men också inom andra former av öppenvård samt mer sluten institutionsvård. På motsvarande vis inkluderar här missbrukarvård dessa tre varianter. Till kategorin försörjningsstöd och arbetslöshet har förutom socialbidragshandläggning och andra försörjningsrelaterade verksamheter inom individ- och familjeomsorgen medräknats socionomer verksamma inom arbetsmarknadsverkets domäner och försäkringskassan. Bland sjukhuskuratorerna återfinns både den somatiska vården och barn- och vuxenpsykiatri (det kan vara värt att notera att vi har vissa skillnader mellan dessa tre kuratorskategorier i flera av våra professionaliseringsindikatorer). Kategorin »allmänt socialbyråarbete» inrymmer dels socialchefer och motsvarande men framför allt socialsekreterare i icke funktionsuppdelade organisationer som arbetar med olika typer av klientärenden (vanligtvis i mindre kommuner). 
Varken valet eller operationaliseringen av våra professionaliseringsindikatorer är helt självklara eftersom det finns uppenbara teoretiska och empiriska problem med att studera professionalisering. Vi utgår här från faktorer som vi menar indikerar professionalisering eller innebär förutsättningar för en sådan, vilket inte är detsamma som att vissa socionomgrupper i realiteten är mer kompetenta och skickliga i sin yrkesutövning. De flesta av våra indikatorer är relativt okomplicerade till sin natur. Andelen som har vidareutbildning av något slag eller som är auktoriserade, syftar på formell kompetensnivå. Därtill jämförs dels andelen som har kontinuerlig handledning, dels genomsnittligt antal yrkesverksamma år. Grundtanken är att professionalisering kan ses som en kontinuerlig process där lärande genom samlade yrkeserfarenheter och handledning betraktas som viktiga för individuell kunskaps- och kompetensutveckling (se vidare Dellgran \& Höjer 2005b).

Andra indikatorer är måhända också självskrivna och mycket relevanta i sammanhanget, men samtidigt klart mer komplexa till sin karaktär och empiriskt svårfångade. Det gäller t.ex. forskningsorientering och de två indikatorer som ska beskriva arbetsvillkorsom här bygger på subjektiva bedömningar och värderingar hos våra respondenter. Intresset för forskning och vetenskaplig kunskap har naturligtvis att göra med att detta anses ha avgörande betydelse för professionaliseringen av en enskild yrkeskår och dess status och legitimitet.

Det senare innebär dock inte automatiskt en ökad användning av en växande mängd forskning och vetenskaplig kunskap i en viss yrkespraktik (Dellgran \& Höjer 2000, 2003c, 2005b). Att studera forskningsanvändning genom att fånga hur vetenskaplig kunskap transformeras och kommer till användning i enskilda beslut, bedömningar och handlingar kräver - om det överhuvudtaget är möjligt - helt andra forskningsmetoder och instrument. ${ }^{7}$ Andelen med en högre grad av forskningsorientering är definierad med hjälp av ett summativt index av svaren på fem frågor, nämligen i vilken grad man bedömer forskning vara en kompetenskälla för egen del, håller sig à jour med relevant forskning, har haft professionell kontakt med forskare, har tilltro till akademisk forskning som ett sätt att utveckla det sociala arbetets praktik samt, själv är intresserad av att söka till en forskarutbildning. De 15 procent av samtliga respondenter som erhöll den högsta summan av svaren (på en femgradig skala) har definierats som de som har en högre grad av forskningsorientering. Det är viktigt att påpeka att den här typen av självdeklarationer alltid innebär en påtaglig risk för ett inslag av social önskvärdhet.

Två andra indikatorer, som också bygger på ett indexförfarande, är tillfredsställelsen med arbetsvillkor respektive autonomi. I enkäten ställdes frågor om i vilken grad man är nöjd respektive missnöjd med 19 olika arbetsvillkor (på en femgradig skala från mycket nöjd till mycket missnöjd).

7 Den empiriska forskningen kring forskningsanvändningen i socialt arbete har i Sverige varit relativt mager, men några undantag är t.ex. Nilsson \& Sunesson (1988), Bergmark \& Lundström (2000) och Socialstyrelsen 2002 (för en bra översikt av den amerikanska forskningen på sådan i just socialt arbete se Kirk \& Reid 2002). 
Bland dessa återfinns t.ex. lön, arbetsuppgifter, arbetsresultat, arbetsbelastning, organisationen, lokala politiker, arbetsledning, metodutveckling, kompetensutveckling, handledning, självständighet, kreativitet, ansvar, möjligheter att planera, psykisk- och fysisk arbetsmiljö. Alternativen poängsattes varefter medeltalet för samtliga respondenter indexerades till 100. På motsvarande sätt skapades ett index som speglar nöjdhet respektive missnöjdhet som bygger på de fyra frågorna om kreativitet, autonomi, ansvar och möjlighet att själv planera sin arbetstid. Tanken är att detta ska återspegla graden av upplevd professionell självständighet.

Återstående två indikatorer, genomsnittlig lönenivå och intern status, kan betraktas som ett sammanlagt resultat av professionaliseringsansträngningar men också av formell kompetens, vidareutbildning och yrkeserfarenheter. Lönenivån är indexerad med avseende på genomsnittlig månadsinkomst inom respektive arbetsområde då yrkesverksamma med arbetsledande befattningar är exkluderade. Intern status bygger här på att respondenterna ombads att, på en femgradig skala från mycket hög till mycket låg, värdera varje enskilt arbetsområdes status (frågans exakta formulering var: "Vilken status upplever du att följande arbetsuppgifter har bland socionomer? «).

Analysen av flyttningsmönster är baserad på en jämförelse mellan hur tre olika utbildningsgenerationer fördelar sig på olika arbetsområden respektive offentlig och privat anställning (examinerade före 1980, 1980-1989 respektive från och med 1990). En viktig anmärkning är att vi på detta sätt inte fångar enskilda socionomers faktiska karriärer, vilket kräver longitudinella eller retrospektiva studier på individnivå. Den generationsspecifika jämförelsen ger här bara indikationer på nettoförändringar över tid. Därför kan vi inte uttala oss om i vilken utsträckning dessa rörelser är ett utslag av traditionella karriärvägar, om de är generationspräglade eller beror på specifika förändringar inom utbildningen eller de verksamheter som organiserar olika former av socialt arbete.

\section{Obalanserad professionalisering}

I Tabell 1 ges en översikt av hur professionaliseringen i tio olika avseenden varierar mellan olika arbetsområden. Översikten innehåller en del förväntade inslag vad gäller skillnader och samband (t.ex. mellan vidareutbildning, yrkesverksamma år och lönenivå). Låt oss göra några punktvisa kommentarer. När det gäller handledning, som sedan länge varit ett professionellt krav, kan vi konstatera att 78 procent av samtliga socionomer i vår undersökning har sådan (i någon form). Allra vanligast är det inom missbrukar- och den sociala barnavården där mer än 90 procent har handledning medan motsvarande andel på socialbidragssidan är klart lägre. Även bland socionomer inom äldre- och handikappomsorgen är handledning mindre förekommande.

Beträffande vidareutbildning har vi $i$ vårt grundmaterial uppgifter om sju olika typer. De i särklass vanligaste är dels interna, vanligtvis kortare och icke högskolebaserade, kurser som hälften av samtliga respondenter har gått, dels fristående kurser på högsko- 
lenivå (44 procent av samtliga). Av Tabell 1 framgår att totalt 7 procent har en magisterexamen, men att en sådan är klart mer sällsynt på socialbidragsområdet och inom missbrukarvården. Detsamma gäller psykoterapiutbildning motsvarande steg 2 som knappt 5 procent av samtliga socionomer har på sitt formella kompetenskonto. Kuratorerna inom sjukvården, och särskilt de som är verksamma inom barn- och vuxenpsykiatrin, tycks med andra ord i större utsträckning föredra terapiutbildningar framför magisterutbildning i socialt arbete. Närmare 13 procent av samtliga var vid enkättillfället auktoriserade, men som framgår av Tabell 1 finns det stora skillnader även på den här punkten. Återigen utmärker sig sjukvårdskuratorer och socionomer som sysslar med psykoterapi eller familjerådgivning av vilka klart fler än genomsnittet var auktoriserade.

Även orienteringen mot forskning skiljer sig mellan olika områden. Så tycks det t.ex. finnas vissa skillnader inom individ- och familjeomsorgen, där forskningsorienteringen verkar vara högre på barnavårdssidan. I genomsnitt är den dock ännu högre bland sjukhuskuratorerna. Vi har tidigare (Dellgran \& Höjer 2003c, 2005b) diskuterat tänkbara orsaker bakom dessa mönster som t.ex. omfattningen av forskning som är eller kan relateras till respektive område. Andra tänkbara hypoteser är att vissa yrkesfält återfinns i organisatoriska kulturer som är mer forskningstäta respektive mer forskningsglesa, eller att forskningsorienteringen påverkas av vidareutbildning - i den professionella karriär som präglas av vidareutbildning, specialisering och byte av arbetsfält följer ett ökat intresse för forskning och vetenskaplig kunskap.
Av vårt grundmaterial framgår att socionomer genomgående är mest missnöjda med lönen av samtliga 19 angivna arbetsvillkor. Intressant att notera i Tabell 1 är annars att arbetsvillkoren uppvisar ett så pass komplicerat mönster. På de områden där man är mer nöjd med sina totala arbetsvillkor så är man också mer nöjd med sin autonomi, vilket t.ex. gäller skolkuratorerna och fältarbetarna. Men också det omvända gäller - är man mer missnöjd så är man också än mer missnöjd med just sin handlingsfrihet och självständighet. Tydligast är detta inom kriminal- och missbrukarvården och på socialbidragssidan. Sannolikt är det på dessa områden som en begränsad professionell diskretion tydligast går hand $\mathrm{i}$ hand med större inslag av kontroll av klienter. Sjukvårdskuratorerna tycks också vara mer missnöjda med sina arbetsvillkor, vilket bl.a. har att göra med att kuratorerna inom barnpsykiatrin t.ex. är lika missnöjda med sin autonomi som socionomer inom socialbidragsområdet. Det här pekar också på ett metodologiskt problem, nämligen att anspråk och inte bara de reella arbetsvillkoren spelar roll för bedömningen. Det är tänkbart att mer välutbildade socionomer har högre anspråk på t.ex. självständighet och möjligheter att göra bruk av den formella och reella kompetens man besitter.

I Tabell 1 kan man konstatera att det finns en mycket tydlig hierarkisk statusordning. Att syssla med psykoterapi eller utbildning och forskning har klart högre status än att arbeta med fattiga, missbrukare, kriminella och äldre och handikappade. Något som inte syns i tabellen, men som framkommer i grundmaterialet, är att arbetet inom barnpsykiatrin har en förhål- 
Tabell I

Professionaliseringsindikatorer inom olika arbetsområden för socionomer 2002.

\begin{tabular}{|c|c|c|c|c|c|c|c|c|c|c|c|}
\hline \multirow[t]{2}{*}{ Arbetsområde } & \multirow{2}{*}{$\begin{array}{c}\text { Andel i } \\
\text { procent av } \\
\text { samtliga } \\
(n=1000)\end{array}$} & \multicolumn{10}{|c|}{ Professionaliseringsindikator } \\
\hline & & $(1)$ & $(2)$ & (3) & (4) & (5) & (6) & (7) & (8) & (9) & $(10)$ \\
\hline Terapi, familjerådgivning m.m. & 6,4 & 21,0 & 91 & 14,5 & 17,5 & 19,0 & 18,9 & 109 & 115 & 1,9 & 113 \\
\hline Utbildning och forskning & 2,3 & 15,8 & 39 & 21,7 & 17,4 & 9,1 & 57,9 & 125 & 131 & 1,9 & 126 \\
\hline Sjukvård & 15,9 & 19,0 & 80 & 5,7 & 13,9 & 21,5 & 16,7 & 98 & 97 & 2,4 & 99 \\
\hline Äldre- och handikappomsorg & 8,0 & 18,2 & 57 & 8,9 & 1,3 & 16,5 & 18,6 & 106 & 106 & 3,6 & 105 \\
\hline Allmänt socialbyrå & 6,5 & 16,3 & 76 & 6,3 & 1,6 & 11,1 & 14,6 & 99 & 99 &. & 97 \\
\hline Skola & 7,3 & 15,9 & 75 & 4,2 & 2,8 & 16,7 & 5,5 & 101 & 113 & 2,7 & 94 \\
\hline Social barnavård & 23,2 & 11,3 & 92 & 9,1 & 0,9 & 10,3 & 14,3 & 95 & 95 & 2,6 & 96 \\
\hline Fält- och samhällsarbete & 1,5 & 9,2 & 79 & 20,0 & 0 & 0 & 33,3 & 109 & 127 & 2,9 & 96 \\
\hline Kriminalvård & 2,4 & 11,4 & 86 & 4,2 & 0 & 8,3 & 23,8 & 99 & 97 & 3,4 & 101 \\
\hline Missbrukarvård & 6,9 & 13,9 & 96 & 0 & 4,4 & 8,8 & 6,7 & 99 & 96 & 3,5 & 99 \\
\hline $\begin{array}{l}\text { Försöriningsstöd, socialbidrag } \\
\text { och arbetslöshet }\end{array}$ & 13,2 & 11,6 & 68 & 1,5 & 0,8 & 8,3 & 4,8 & 95 & 93 & 3,7 & 95 \\
\hline Övriga & 6,3 & 16,3 & 41 & 4,8 & 1,6 & 6,6 & 18,9 & 110 & 111 & - & 111 \\
\hline Samtliga & 100,0 & 14,9 & 78 & 6,8 & 4,8 & 12,8 & 14,8 & 100 & 100 & - & 100 \\
\hline
\end{tabular}

(1) Genomsnittligt antal yrkesverksamma år som professionell socialarbetare (anova, $\mathrm{p}<0,001$ ).

(2) Andel med handledning (chi2, $\mathrm{p}<0,001$ ).

(3) Andel med magisterutbildning (chi2, $\mathrm{p}<0,001$ ).

(4) Andel med terapiutbildning, steg 2 (chi2, p<0,001).

(5) Andel auktoriserade (chi2, $\mathrm{p}<0,001$ ).

(6) Andel med högre grad av forskningsorientering baserat på summativt index av fem frågor med självdeklarerade värderingar av forskning som kompetenskälla, grad av att hålla sig à jour med relevant forskning, kontakt med forskare, bedömning av forskningens möjligheter att förbättra framtida socialt arbete samt graden av intresse att själv syssla med forskning och söka in på forskarutbildning. Femgradiga skalor (anova, $\mathrm{p}<0,001)$.

(7) Genomsnittlig tillfredsställelse med avseende på nitton aspekter (lön, arbetsuppgifter, arbetsresultat, organisation, lokala politiker, metod- och kompetensutveckling, handledning, fysisk och psykosocial arbetsmiljö, arbetsledning, kreativitet, ansvar, arbetsplanering, självständighet m.fl. (femgradiga skalor). Index där genomsnittet för samtliga $=100$ (anova, $\mathrm{p}<0,001$ ).

(8) Genomsnittlig tillfredsställelse med autonomi, som (7) ovan men enbart med avseende på fyra variabler (kreativitet, ansvar, planering och självständighet). Index där genomsnittet för samtliga $=100$ (anova, $\mathrm{p}<0,001)$.

(9) Genomsnitlig status inom socionomkollektivet enligt respondenterna, femgradig skala från $1=$ mycket hög till 5= mycket låg intern status.

(10) Genomsnittlig månadsinkomst (respondenter med arbetsledande uppgifter exkluderade). Index där genomsnitt för samtliga $=100$ (anova, $\mathrm{p}<0,001$ ). 
landevis hög intern status. Statusskillnader tycks också ha att göra med lönenivå, även om vi här kan tänka oss ett kausalt förhållande åt båda hållen. En intressant avvikelse från detta mönster är socionomer inom omsorgen som har en genomsnittlig lönenivå som ligger över genomsnittet trots en klart lägre intern status (och trots en i övrig låg lönenivå bland andra yrkeskategorier inom t.ex. äldreomsorgen).

Det sammanlagda intrycket är att vi, måhända inte överraskande, har att göra med en obalanserad professionalisering. Två områden - terapi och familjerådgivning respektive utbildning och forskning - framstår som mer professionaliserade i de avseenden som vi har undersökt. Här kombineras en högre vidareutbildningsnivå, en högre grad av forskningsorientering och en större tillfredsställelse med arbetsvillkor med klart högst intern status och lönenivå. På motsvarande vis finner vi att framför allt socialbidrags- och arbetslöshetsområdet i dessa avseenden är klart mindre professionaliserat (se också Billquist \& Dellgran 2003). Mellan dessa ytterligheter finner vi ett stort antal områden som uppvisar ett mer varierat mönster - mer professionaliserade på vissa punkter och mindre på andra. Vi kan lugnt konstatera att vi har att göra med ett stratifierat yrkesfält.

\section{Professionalisering som individuella karriärer}

Det sistnämnda för oss över till frågan om karriärvägar. I Tabell 2 återfinns en jämförelse av hur våra tre utbildningsgenerationer fördelar sig på de olika arbetsom- råden som nyss har beskrivits. I tabellen finns också ett "flyttningsnetto« som anger vilka områden som socionomerna över tid lämnar respektive söker sig till. Som synes finner vi mycket stora variationer i vad de olika generationerna sysslar med. Särskilt tydligt är det att andelen som arbetar inom individ- och familjeomsorgen är klart högre i den yngsta generationen. Framför allt är det den sociala barnavården och försörjningsstödet som på det här viset förlorar sina yrkesverksamma medan minskningen på missbrukssidan är något mindre. På motsvarande vis återfinns den äldsta generationen i mycket större utsträckning inom sjukvården och inom det terapeutiska fältet. De enda områden som inte har en successiv ökning respektive minskning mellan generationerna är missbrukarvården och skolkuratorerna.

Ett annat sätt att formulera detta är att en vanlig karriärväg som nyutexaminerad socionom är att börja sin bana på socialkontor (av de närmare 100 respondenter $\mathrm{i}$ vårt material som är examinerade de tre senaste åren återfinns 70 procent just på socialkontor). Efter ett tag går man via ökad kompetens och meritering vidare till arbetsområden med högre status, lön och utrymme för professionell handlingsfrihet. Som vi nyss var inne på kan det också tänkas att det är just en begränsad diskretion, högre grad av politisk styrning och ett tydligare inslag av kontroll och myndighetsutövning i klientarbetet, som skapar incitament för att lämna vissa områden och söka sig till andra. I vårt enkätmaterial framkommer att totalt 65 procent av samtliga tillfrågade under någon period i sitt yrkesliv har arbetat med social barnavård, 63 procent på motsvarande vis

Peter Dellgran \& Staffan Höjer: Rörelser i tiden. Professionalisering och... 
med försörjningsstöd och 47 procent med missbrukarvård. Om man betänker att dessa områden idag svarar för 23, 13 respektive 7 procent av samtliga socionomer så får man en viss uppfattning om den stora genomströmning av personal som präglar dessa fält.

Återigen bör vi understryka att vår jämförelse inte säger något om de faktiska, individuella flyttningsrörelserna och karriärerna som kan vara mer krokiga och komplexa. Vi vet inte heller hur de karriärvägar vi sätter fingret på har förändrats över tid. Det återstår att undersöka hur strukturella förändringar av arbetsvillkor eller betingelser för kompetensutveckling påverkar incitamenten hos olika utbildningsgenerationer till professionella karriärer och för- flyttningar mellan arbetsområden eller att, som vi nu ska gå över till, gå från offentlig till privat verksamhet.

\section{Privatisering bland socionomer - kännetecken och motiv}

Av vår studie framgår att cirka 7 procent av socionomerna i varierande grad arbetar i egen privat regi, vilket kan jämföras med 3 procent som är anställda i privata företag eller ideella organisationer och den stora majoritet på närmare 90 procent som har offentliga arbetsgivare. Det är dock bara en liten del av de privata som arbetar heltid (drygt 1 procent av samtliga respondenter). Närmare två tredjedelar arbetar 20 pro-

\section{Tabell 2}

Yrkesverksamma socionomer examinerade under olika tidsperioder fördelade på arbetsområden i procent $(n=1000, p<0,001)$.

\begin{tabular}{lccccc}
\hline Område & Totalt & $\begin{array}{c}-1979 \\
\text { (a) }\end{array}$ & $\begin{array}{c}1980-89 \\
\text { (b) }\end{array}$ & $\begin{array}{c}1990- \\
\text { (c) }\end{array}$ & $\begin{array}{c}\text { Flyttningsnetto } \\
\text { (a)-(c) }\end{array}$ \\
\hline Social barnavård & 23,3 & 12,1 & 19,0 & 36,4 & $-24,3$ \\
Sjukvård & 15,8 & 24,2 & 16,8 & 7,9 & 16,3 \\
$\begin{array}{l}\text { Försöriningsstöd, socialbidrag och arbets- } \\
\text { löshet }\end{array}$ & 13,4 & 7,8 & 14,6 & 17,0 & $-9,2$ \\
Social omsorg & 8,0 & 11,1 & 8,2 & 5,2 & 5,9 \\
Skola & 7,3 & 7,2 & 10,1 & 4,9 & 2,3 \\
\hline Missbrukarvård & 6,9 & 4,9 & 8,5 & 7,1 & $-2,2$ \\
Allmänt socialbyrå & 6,5 & 6,9 & 6,0 & 6,6 & 0,3 \\
\hline Individ- och familjeterapi,familjerådgivning mm & 6,4 & 12,1 & 5,1 & 2,7 & 9,4 \\
Kriminalvård & 2,4 & 1,3 & 1,9 & 3,8 & $-2,5$ \\
\hline Utbildning och forskning & 2,3 & 4,2 & 2,5 & 0,5 & 3,7 \\
Fält- och samhällsarbete & 1,5 & 0,3 & 1,3 & 2,7 & $-2,4$ \\
Övriga & 6,2 & 7,8 & 6,0 & 4,9 & 2,9 \\
\hline Totalt, procent & 100,0 & 100,0 & 100,0 & 100,0 & \\
antal & 987 & 306 & 316 & 365 &
\end{tabular}


cent eller mindre med sin egna verksamhet, vilket innebär att man samtidigt är offentliganställd. Det värt att notera att närmare 7 procent av enbart offentligt anställda tidigare har arbetat i egen privat regi, men av olika anledningar valt att återgå till offentligt arbete på heltid.

Av Tabell 3 framgår att socionomer med privat verksamhet generellt sett är äldre och har en längre yrkeserfarenhet jämfört med de som enbart arbetar i offentlig regi.
Dessutom är andelen män något högre bland de privata. Däremot finns inga signifikanta skillnader när det gäller partisympatier - andelen socialistiska väljare är 73 procent $\mathrm{i}$ båda grupperna, vilket dels visar att socionomer är mer vänsterinriktade än befolkningen i sin helhet, dels indikerar att valet att starta eget inte verkar vara fattat på ideologiska grunder, något som vi strax ska återkomma till. Detta utgör en skarp kontrast till socionomernas generella atti-

\section{Tabell 3}

Socionomer i egen privat regi respektive offentlig regi. Nägra kännetecken och professionaliseringsindikatorer $(n=1000)$.

\begin{tabular}{|c|c|c|c|}
\hline & $\begin{array}{l}\text { Egen privat regi } \\
\quad(\mathrm{n}=68)\end{array}$ & $\begin{array}{l}\text { Offentlig regi } \\
(n=864)\end{array}$ & Sign. test ${ }^{8}$ \\
\hline Andel män, procent & 27,9 & 16,4 & * \\
\hline Andel födda före 1950, procent & 50,0 & 24,7 & ******* \\
\hline Andel utbildade före 1980, procent & 55,2 & 28,5 & **** \\
\hline $\begin{array}{l}\text { Antal yrkesverksamma år (som professionell socialar- } \\
\text { betare), medeltal }\end{array}$ & 21,6 & 14,4 & ******* \\
\hline Andel med socialistiska partisympatier, procent ${ }^{9}$ & 73,5 & 73,1 & n.s. \\
\hline Andel med handledning, procent & 72,3 & 73,0 & n.s. \\
\hline Andel med magisterutbildning i socialt arbete, procent & 11,8 & 6,4 & n.s. \\
\hline Andel med handledarutbildning, procent & 41,2 & 7,8 & ***** \\
\hline Andel med terapiutbildning, steg I, procent & 48,5 & 17,3 & **** \\
\hline Andel med terapiutbildning, steg 2, procent & 29,4 & 3,0 & ****** \\
\hline Andel med forskarutbildning, procent & 5,9 & 0,6 & ***** \\
\hline Andel auktoriserade, procent & 16,2 & 12,2 & n.s. \\
\hline Forskningsorientering, procent med en högre grad & 27,0 & 14,0 & * \\
\hline Arbetsvillkor,grad av nöjdhet (index, total=|00) & 118 & 99 & ****** \\
\hline Autonomi, grad av nöjdhet (index, total=100) & 115 & 99 & * \\
\hline Månadsinkomst, genomsnitt i kr & 25300 & 20800 & 米米米 \\
\hline
\end{tabular}

8 Signifikanstester: chi2 för procentvariabler och anova för genomsnittsvariabler. För båda procedurerna: $\left.{ }^{*}=\mathrm{p}<.05,{ }^{* *}=\mathrm{p}<.01,{ }^{* * *}=\mathrm{p}<.001\right)$.

9 Med socialistiska partisympatier menas här någon av vänsterpartiet, social demokraterna eller miljöpartiet.

Peter Dellgran \& Staffan Höjer: Rörelser i tiden. Professionalisering och... 
tyder kring privatisering av välfärdstjänster i allmänhet som vi tidigare har visat har tydliga ideologiska förtecken (Dellgran \& Höjer 2003a).

De vanligaste verksamheter som privata socionomer sysslar med är handledning (55 procent), individ- och/eller familjeterapi (48 procent), utbildning (42 procent) och rådgivning (39 procent). Något färre sysslar med utvärderingar (11 procent) och utredningar (8 procent) eller driver behandlingsinstitutioner ( 8 procent). ${ }^{10}$ En övervägande majoriteten av socionomer med privat verksamhet återfinns alltså inom de två områden som tidigare har beskrivits som de mest professionaliserade.

När det gäller motiven till att starta eget bad vi de respondenter som bedriver verksamhet i egen regi att värdera ett antal möjliga faktorer, av vilka några bygger på våra hypoteser om privatisering som en professionaliseringsstrategi. Av Tabell 4 framstår intresset för kontroll och självständighet som de starkaste motiven, vilket också har bekräftats i våra intervjuer. Andra förhållandevis vanliga motiv är behovet av omväxling och utmaningar. Relativt många håller också med om att inkomstaspekten spelar en viss roll. $\mathrm{Nu}$ måste vi hålla i minnet att social önskvärdhet eller uppfattningar om vad som kan sägas vara politiskt (och professionellt) korrekt kan ha inneburit en viss underskattning av inkomstens betydelse i sammanhanget (se också Dellgran \& Höjer 2005a).

10 Många håller på med mer än en typ av verksamhet. I mindre omfattning förekommer även bl.a. mellanvårdsinsatser, privat familjehemsverksamhet (rekrytering och stöd), samt andra typer av konsulttjänster.
Även om vissa av våra respondenter menar att missnöje med tidigare arbetsplatsförhållanden och möjligheter till professionell utveckling inom offentligt organiserat socialt arbete har spelat en betydande roll för deras val att starta eget, så verkar detta ha spelat en något mindre roll jämfört med intresset av kontroll över sin arbetssituation och självständighet om man ser till gruppen i sin helhet. Troligtvis finns det ett element av missnöje med villkoren i det offentliga också i dessa motiv - i många av våra intervjuer framträder också med all önskvärd tydlighet hur dessa aspekter är två sidor av samma mynt. Endast en liten del av respondenterna menar att deras beslut att starta eget utgick från överväganden som hade att göra med familjesituation eller risken för arbetslöshet. Som vi nyss nämnde verkar inte heller ideologiska aspekter ha spelat någon större roll i sammanhanget.

En tredjedel av våra respondenter med egen verksamhet håller med om påståendet att "(d)et fanns ingen plats för denna verksamhet inom det offentliga", vilket antyder ett ytterligare sätt att förstå drivkrafterna bakom en spontan eller professionsdriven privatisering. Även i våra intervjuer har vi fått ta del av åtskilliga beskrivningar där socialarbetare, inom ramen för en tidigare offentlig verksamhet, har utvecklat speciella program, modeller eller metoder, ibland organiserade i projektform, som man efter en tid, och av olika skäl (politiska, finansiella etc.) tvingats lägga ned. Många har därefter istället startat en privat verksamhet för att fortsätta att utveckla sina arbetsmetoder (och ibland, ironiskt nog, sålt samma tjänster till den offentliga myndighet där man själv tidigare var anställd). I den mån vi på 
detta sätt bevittnar en utveckling av vissa typer av tjänster som ett resultat av en ny utbuds-efterfråge-dynamik, så utmanar detta den relativt vanliga bilden av ett nollsummespel i synen på relationerna mellan offentliga och privata tjänster, dvs. där t.ex. socialt arbete antingen är offentligt eller privat.

Utifrån de flesta indikatorer som återfinns i Tabell 3 har socionomer i egen regi en högre professionaliseringsgrad än de enbart offentligt anställda. De förstnämnda är i genomsnitt äldre och har en längre yrkeser- farenhet. Dessutom är de mer välutbildade och deklarerar en högre grad av orientering gentemot forskning. Utan att veta i vilken mån bedömningarna om arbetsvillkor gäller deras privata eller offentliga verksamhet (de flesta jobbar ju endast privat på deltid), så är de privata i genomsnitt mer nöjda med sina arbetsvillkor (särskilt gäller detta självständighet, kompetensutveckling och arbetsresultat). Och som om detta inte vore nog så tjänar de dessutom i genomsnitt mer pengar än de enbart offentlig anställda. Vid sidan av andelen som har tillgång till

\section{Tabell 4}

Motiv bland privata socionomer för att arbeta med socialt arbete $i$ egen privat regi, balansmått $(n=68)$.

\begin{tabular}{lc}
\hline Motiv & Balansmått \\
\hline Högre kontroll över arbetsuppgifter & 75,4 \\
\hline Större självständighet & 63,6 \\
\hline Mer kontroll över arbetstiden & 62,1 \\
\hline Behov av omväxling & 54,5 \\
\hline Behov av utmaning & 49,3 \\
\hline Möjlighet till specialisering & 48,5 \\
\hline Att bli sin egen chef & 29,8 \\
\hline Högre inkomst & 27,4 \\
\hline Det fanns ingen plats för denna verksamhet inom det offentliga & 21,2 \\
\hline Att undvika byråkrati & 10,4 \\
\hline Högre status & 1,6 \\
\hline Missnöje med tidigare arbetsvillkor & $-3,2$ \\
\hline Missnöje med tidigare möjligheter till professionell utveckling & $-13,7$ \\
\hline Familjesituationen & $-46,0$ \\
\hline Ideologi och värderingar & $-50,0$ \\
\hline Krav från uppdragsgivare & $-72,5$ \\
\hline Alternativ till arbetslöshet & $-74,6$ \\
\hline
\end{tabular}

Balansmått är procentandelar »instämmer« minus »tar avstånd ifrån»

Peter Dellgran \& Staffan Höjer: Rörelser i tiden. Professionalisering och... 
handledning så finns det egentligen bara en gemensam nämnare (av de som vi här har undersökt) för de två grupperna - de är lika vänsterorienterade i sina partisympatier.

\section{Från offentligt till privat?}

För att ytterligare belysa frågan om professionalisering kan ta sig uttryck i en privatisering ska vi studera hur våra tre utbildningsgenerationer fördelar sig på offentlig respektive privat verksamhet. Som framgår av Tabell 5 är det klart vanligare med självanställning i den äldsta generationen. Andelen med privat verksamhet är här närmare 13 procent medan motsvarande andel bland 90-talisterna stannar vid knappt 3 procent. En tolkning av detta är att professionaliseringen i termer av individuella karriärer för många socionomer innebär att man rör sig uppåt till arbetsområden och arbetsuppgifter som i större utsträckning också erbjuder möjligheter att bedriva verksamhet i just privata former (som psy- koterapi, rådgivning, handledning, utbildning och utvärdering).

På frågan om det går att skönja en tendens till ökad privatisering, kan vi konstatera att en fjärdedel har startat sin privata verksamhet inom en tvåårsperiod före enkättillfället och närmare tvåtredjedelar under den senaste femårsperioden. Detta kan å ena sidan indikera en samtidsrelaterad ökning av fenomenet, t.ex. beroende på attitydförändringar eller ökad efterfrågan på köpta tjänster. $\AA$ andra sidan kan expansionen av vidareutbildning och annan kompetensutveckling ha inneburit att allt fler socionomer har fått reella möjligheter att starta eget. Som vi redan har nämnt har många helt offentliganställda tidigare haft en egen verksamhet - andelen i den äldsta gruppen uppgår här till närmare 11 procent, vilket kan jämföras med 7 procent för mellangruppen och knappt 3 procent bland examinerade efter 1990. Detta betyder att totalt närmare en fjärdedel av samtliga socionomer som examinerades på 1970-talet har eller har haft en egen privat verksamhet.

\section{Tabell 5}

Yrkesverksamma socionomer examinerade under olika tidsperioder fördelade $i$ privat och offentlig anställning i procent ( $n=1000, p<0,001)$.

\begin{tabular}{lccccc}
\hline Område & Totalt & $-1979(\mathrm{a})$ & $1980-89(\mathrm{~b})$ & $1990-(\mathrm{c})$ & $\begin{array}{c}\text { Flyttningsnetto } \\
\text { (a)-(c) }\end{array}$ \\
\hline $\begin{array}{l}\text { Egen privat (helt eller } \\
\text { delvis) }\end{array}$ & 7,4 & 12,8 & 7,5 & 2,0 & 10,0 \\
$\begin{array}{l}\text { Privat anställd } \\
\begin{array}{l}\text { Offentligt anställd } \\
\text { (enbart) }\end{array}\end{array}$ & 9,3 & 2,8 & 1,0 & 4,0 & $-1,2$ \\
\hline $\begin{array}{l}\text { Totalt, procent } \\
\text { antal }\end{array}$ & 100,0 & 100,0 & 100,0 & 100,0 & $-9,6$ \\
& 987 & 306 & 316 & 365 & \\
\hline
\end{tabular}




\section{Rörelser i tiden - och i framtiden}

Vår genomgång belyser i några avseenden hur professionaliseringen av det sociala arbetet har framskridit och hur det professionella projektets landvinningar kan beskrivas. Vid en hastig anblick framträder socialt arbete som en framgångshistoria. Antalet yrkesverksamma socionomer är större än någonsin. Socionomutbildningen har under många år varit en mycket populär universitetsutbildning. Allt fler högskolor har startat socionomutbildningar. Nyutexaminerade har under en lång period haft mycket lätt att finna arbetstillfällen och arbetslöshet har varit mycket sällsynt, även om det i skrivande stund finns tecken på en förestående tuffare arbetsmarknad. Inom vissa arbetsområden kan socionomerna sägas ha kommit närmare ett yrkesmonopol i förhållande till andra professioner. Det har under de senaste tjugo åren skett en transformering av socionomutbildningen som har inneburit att socialt arbete förstärkt sin position som teoretiskt huvudämne. Under samma tid har forskarutbildningarna utvecklats och bland annat producerat över 170 doktorer i ämnet socialt arbete och lika många doktorsavhandlingar samt en snabb ökning av senior forskning och ett ökat antal docenter och professorer (Sunesson 2003, Dellgran \& Höjer 2003c). Lägger vi till denna bild att en stor majoritet av socionomerna idag har handledning, att antalet auktoriserade ökar samt att allt fler vidareutbildar sig, så förstärks bilden av fortsatt professionalisering i såväl individuell som kollektiv mening.

Däremot återstår det att avgöra i vilken mån detta sammantaget har påverkat socionomernas professionella status och legitimitet i relation till staten, andra professionella grupper eller allmänheten. Det finns också andra, mindre framgångsrika och i ett professionaliseringsperspektiv ganska viktiga inslag. Så är t.ex. alltjämt lönerna låga $i$ jämförelse med andra yrkesgrupper med motsvarande lång högskoleutbildning. Dessutom har staten, trots många års påstötningar, sagt nej till socionomernas krav på ett legitimationssystem. Därtill är den politiska styrningen fortfarande för stark vilket illustrerar vissa svårigheter för professionen att flytta fram sina positioner ytterligare.

Professionalisering av ett yrkesområde innebär också interna förändringar. På socionomfältet framstår vissa arbetsområden och grupper som mer professionaliserade än andra, ett mönster som sannolikt går att återfinna också inom andra välfärdsområden. Det existerar en inre hierarkisk statusordning som är så väletablerad att studenterna på socionomutbildningarna redan på sin första termin kan återge den i sina huvuddrag. Studenternas yrkesmässiga intresse följer också i viss mån statusordningen. Att döma av vår enkät med 801 svarande socionomstudenter tycks de mest eftersträvansvärda områdena vara terapi, familjerätt, barnpsykiatri och skolkurativt arbete. Klart mer begränsat är intresset för missbrukarvård, äldreomsorg och försörjningsstöd. Möjligtvis avspeglar detta en mer generell samhällspräglad ordning, vilket naturligtvis inte gör saken mycket lättare.

Vi kan här inte avgöra huruvida den obalanserade professionaliseringen, stra-

Peter Dellgran \& Staffan Höjer: Rörelser i tiden. Professionalisering och... 
tifieringen av arbetsvillkor eller statusordningen har förstärkts, men den är i sig ett problem och innebär speciella utmaningar för de professionella själva, för utbildningsansvariga och för kommunala och andra organisationer. En obalans mellan olika arbetsområden ger incitament till rörelser från arbeten med sämre villkor till områden med bättre sådana. Indirekt innebär detta också incitament till vidareutbildning som ett sätt att öka den formella kompetensen och därigenom möjliggöra sådana förflyttningar. Vidareutbildning innebär i sig ökade krav, förväntningar och anspråk bland de yrkesverksamma på att få utnyttja sin ökade kompetens. Om dessa inte kan tillfredsställas inom befintlig tjänst, t.ex. genom specialisering eller ökat professionellt handlingsutrymme, ökar rimligtvis intresset av att byta till andra verksamheter med bättre sådana betingelser. Risken är med andra ord att rörelsen från traditionellt klientarbete med myndighetsutövning och kontrollinslag till arbete med andra klientgrupper, eller med andra professionella på det här viset förstärks.

En tilltagande stratifiering bör framför allt vara ett problem för den kommunala individ- och familjeomsorgen i termer av rekryteringsproblem och svårigheter att behålla personal. Våra data ger en tydlig bild av socialbyrån som ett ingångs- och exitområde, vilket innebär hög personalomsättning, kontinuitetsproblem och kostnader för introduktion och lärande. En försämring i termer av reducerad diskretion, minskat professionellt inflytande över metoder och organisationsformer eller sämre betingelser för kompetensutveckling riskerar att skapa missnöje och ökat intresse bland de anställda att lämna socialkontoren.

Beträffande privatiseringen som en form av professionalisering kan vi dra åtminstone tre slutsatser. För det första handlar det fortfarande om ett fenomen på marginalen, även om vi kan ana en viss ökning av socionomer med privat verksamhet under de senaste åren som tycks vara betingad av såväl strävan mot oberoende som missnöje med arbetsvillkoren inom det offentliga. För det andra har vi tidigare konstaterat att det finns tydliga tecken på attityd- och intresseförändringar bland yngre socionomer och studenter (Dellgran \& Höjer 2003b). Vi kan ana en tilltagande ambivalens och förskjutning i synsätten - mindre av ideologiska och mer av professionellt baserade ståndpunkter och överväganden. Bilden verkar allt mer präglas av pluralism och pragmatism. För det tredje framträder ett visst samband mellan övergången till privat verksamhet och byte av arbetsområden, vilket sammanhänger med att förutsättningarna för privata former är bättre inom vissa områden. Nya generationer av välutbildade socionomer och en fortsatt professionalisering genom ökad forskningsorientering, specialisering och vidareutbildning, med målet att öka professionell status, kontroll och självständighet, kan med andra ord innebära såväl en ökad privatisering som en allt tydligare rörelse mot arbetsområden med högre status (och med färre eller inga klienter). Frågan är om vi därigenom får en utveckling likt den amerikanska och vad priset för detta i så fall kommer att bli. 


\section{Referenser}

Alexander, P.M. (1987) „Why social workers enter private practice». A study of motivations and attitudes. Journal of Independent Social Work, Issue 1 s. 7-18.

Becher, T. (1999) Professional Practices. Commit ment \& Capability in a Changing Environment. New Brunswick: Transaction Publishers.

Bergmark, Å. \& Lundström, T. (2000) "Om socialarbetare inom socialtjänsten". Socionomens forskningssupplement $\mathrm{nr} 12$.

Billquist, L. \& Dellgran, P. (2003) "Arbete med försörjningsstöd - ett eftersatt område». Socionomen, nr 6 2003, s. 18-22.

Blom, B. (1998) Marknadsorientering av socialtjänstens individ- och familjeomsorg. Om villkor, processer och konsekvenser. Akad avh, institutionen för socialt arbete, Umeå universitet

Burrage, M. \& Torstendahl, R. (eds.) (1990) Professions in Theory and History. London: Sage.

Butler, A. (1992) »The attractions of private practice». Journal of Social Work Education. Vol. 28 Issue 1 s. 47-60.

Camilleri, P.J. (1996) (Re)Constructing Social Work. Exploring Social Work through Text and Talk. Aldershot: Avebury.

Chung, W.S, Fitzpatrick, S. \& Pardeck, J. (1995) „Private and nonprofit Practitioners: An exploratory Study". Social Work \& Social Sciences Review, 6,2, s. 98-109.

Dellgran, P. \& Höjer, S. (1999) „När studenten själv får välja». Om uppsatser i socionomutbildningen och dess roll för professionaliseringen av socialt arbete Socionomens forskningssupplement 5 s. 30-48.

Dellgran, P. \& Höjer, S. (2000) Kunskapsbildning, akademisering och professionalisering $i$ socialt arbete. Akad avh, institutionen för socialt arbete, Göteborgs universitet.

Dellgran, P. \& Höjer, S. (2003a) „Unbalanced professionalisation. On Status and Stratification in Swedish Social Work". Social Work in Europe Vol. 10 No 2 s. 37-48.

Dellgran, P. \& Höjer, S. (2003b) »En delad och ambivalent profession. Socionomers attityder till privatisering av socialt arbeter. Socionomens forskningssupplement $\mathrm{nr} 15$ s 17-36.

Dellgran, P. \& Höjer, S. (2003c) »Forskning i praktiken". I Högskoleverket 2003, Socialt arbete. En genomlysning av ämnet. Högskoleverkets rapportserie 2003:16.

Dellgran, P. \& Höjer, S. (2005a) „Privatisation as professionalisation? Attitudes, motives and achievments among Swedish social workers" European Journal of Social Work vol. 8, nr 1, s.39-62.

Dellgran, P. \& Höjer, S. (2005b) "Sources of knowledge and relations between research, education and practice in professional social work". I Månsson, S-A. \& Proveyer, C. (red.) Social Work in Cuba and Sweden. Achievements and Prospects. Göteborg university.

Evans, T. \& Harris, J. (2004) „Streey-level bureaucracy, social work and the (exaggerated) death of discretion" British Journal of Social, 34, (6) s. 871-895.

Freidson, E. (1994) Professionalism Reborn. Oxford: Blackwell Publishers.

Gieryn, T. (1999) Cultural Boundaries of Science. Credibility on the Line. Chicago: The Univeristy of Chicago Press.

Harris, J. (2004) The Social Work Business. London: Routledge.

Jayaratne, S., Davis-Sacks, M.L\& Chess W.A. (1991) "Private practice may be good for your health and well-being". Social Work 36 s. 224-229.

Kayser, J. \& Rotsthein, J. (1997) "MSW students in private practice: Conflicts and challenges for social work education". Journal of Social Work Education Vol 33:3 s. 507-517.

Kirk, S.A. \& Reid, W.J. (2002) Science and Social Work. A critical appraisal. New York: Columbia University Press.

Larson, M. (1977) The Rise of Professionalism. A Sociological Analysis. Berkeley: University of California Press.

Lowe, G.R. \& Reid, P.N. (1999) Professionalization of Poverty. Social Work and the poor in the Twentieth Century. New York: Aldine de Gruyter.

Macdonald, K. (1995) The sociology of the professions. London: Sage.

Peter Dellgran \& Staffan Höjer: Rörelser i tiden. Professionalisering och... 
McDonald, C. (2003) „Forward via the Past? Evidence-Based Practice as Strategy in Social Work", The Drawing Board: An Australian Review of Public Affairs, vol 3, no 3, s.123-142.

Manthorpe, J. \& Stanley, N. (1997) »Private placements in social work education: Opportunity or opression? " I Social Work Education, vol 16, s. 66-79.

Martin, E. W. (1992)»Themes in a history of social work profession« i International Social Work, s. 327-35.

Munn, P. \& Kennedy, M. (1994) "Consultancy work: An option for social work towards the 21st century" i Australian Social Work, vol 47, s 11-14.

Nilsson, K. \& Sunesson, S. (1988) Konflikt, kontroll, expertis. Lund: Arkiv.

Nygren, L. (2000) "Har det sociala arbetet en teoretisk kärna?" I Meeuwisse A. \& Swärd H. Socialt arbete en grundbok. Stockholm: Natur och Kultur.

Payne, M. (1996) What is professional social work. Birmingham: Venture Press.

Peat, B. \& Costley, D.L (2000) "Privatization of social services:correlates of contract performance». Administration in Social Work $24 \mathrm{~s}$. 21-38.

Pettersson, U. (red) (1994) Socialtjänstens klientarbete - från vision till marknad? Lund: Studentlitteratur.

Rigné, E.M. (2002) Profession, Science and State. Psychology in Sweden 1968-1990. Department of Sociology, Göteborg university.
Rosenman, L. (1989) „Privatisation of social welfare services and social work practice: An overview of the issues" i Australian Social Work, vol 42 , s. $5-10$.

Socialstyrelsen (2002) Utvärdering av FoU - En studie av FoU-enheter inriktade på individ- och familjeomsorg. Rapport Socialstyrelsen.

Specht, H. \& Courtney, M. (1994) Unfaithful angels. How Social Work has Abandoned its Mission. New York: Free Press.

Starr, P. (1989) »The meaning of privatization", i Kamerman S B \& Kahn A (red.) (1989) Privatization in and the Welfare States. Princeton: Princeton University Press.

Strom, K. (1994) „Clinicans'Reasons for Rejecting Private Practice». Families in Society, 75, 8, s. 499-508.

Sunesson, S. (2003) "Socialt arbete - en bakgrund till ett forskningsämne«. I Högskoleverket 2003, Socialt arbete. En genomlysning av ämnet. Högskoleverkets rapportserie 2003:16.

Svensson, L.G. (1998) Professionalisering och politisk decentralisering - En sociologisk studie av skolan och socialtjänsten $i$ en kommundelsreform. Research report No 122. Sociologiska inst., Göteborgs universitet.

van Heugten, K. \& Daniels, K. (2001) "Social workers who move into private practice: The impact of the socio-economic context « i British Journal of Social Work, vol 31, s. 739-755.

Wingfors, S. (2004) Socionomyrkets professionalisering. Akad. avh. Göteborgs universitet, sociologiska institutionen. 


\section{Summary}

\section{Movements in our times Professionalization and privatization in social work}

The Swedish welfare state is in constant transition. The organization of public service production is influenced by different kinds of processes including the political changes and management on the one hand and the professionalization of occupations on the other. The aim of this article is twofold. First, the intention is to describe and discuss differences of professionalization among trained social workers active in different occupational fields within social work. Questions at issue include (i) a characterization of professionalization in terms of advanced education and supervision, (ii) comparisons between different working areas, (iii) the differences of professionalization between social workers in public and private practice. The second aim is to illuminate career patterns for social workers, focusing on the movements between different working areas and between public and private practice.

The study is based on a survey with exactly 1,000 responding professional social workers. The survey was sent to a random selection of social workers in the largest social work union and had an estimated response rate of over 71 per cent. The result shows clear imbalances and stratifications in terms of professionalization between social workers in different working areas. Therapy and family counselling, along with education and research, turn out to be the most professionalized areas, whereas social assistance and the field of unemployment are the least professionalized. When indicators of professionalization are compared, private practitioners rate higher than publicly employed ones. The individual career patterns among social workers show movements towards areas with a higher level of professional discretion, higher status and wages. In the final discussion problems connected with increased stratification are presented. Connections are also noted between privatization and professionalization in social work. 